\title{
INSTRUMENTS TO MEASURE NURSES' KNOWLEDGE AND SKILLS IN IMPLEMENTING EVIDENCE-BASED PRACTICE: A LITERATURE REVIEW
}

\author{
Wahyu Hidayat ${ }^{1}$, Syahrul Said ${ }^{2}$ \\ ${ }^{1}$ Dosen, Sekolah Tinggi Ilmu Kesehatan Mega Buana Palopo \\ ${ }^{2}$ Dosen Fakultas Keperawatan, Universitas Hasanuddin Makassar \\ e-mail: wahyu.aries91@gmail.com
}

\begin{abstract}
Introduction: There are available instruments to measure nurses' knowledge and skills related to Evidence-Based Practice (EBP) implementation. The purpose of this study is to investigate the instrumentsto evaluate knowledge and skills of nurses in the application of evidence-based practice. Methode: Searching for resources using keywords to find instruments to measure nurses' knowledge and skills in implementing EBP in Pubmed and Willey databases, and then using Critical Assessment Capability Program (CASP) for cross sectional study as a tool to extract the publications obtained. Result: Eleven publications were analyzed descriptively, only two publications used the same instrument. But does not mean that the instruments used by other researchers are invalid. Conclusions: This literature review have not been able to explain which instrument is better to use in measuring EBP nurses' knowledge and skills. The instrument to be used needs to pay attention to the appropriateness of the contents of the instrument to the organization's organizational culture so that the results of the measurements taken can provide valid data.
\end{abstract}

Keywords: Instrument, Knowledge, Skill, Evidence-Based Practice.

\section{PENDAHULUAN}

Mengintegrasikan evidencebased practice (EBP) ke dalam praktik pelayanan keperawatan merupakan sebuah standar yang harus di penuhi oleh rumah sakit baik secara nasional maupun internasional (IOM, 2011; KARS, 2017; Melnyk et al., 2016). Penelitian keperawatan yang dilakukan dapat memberikan pengetahuan terkait penggunaan bukti dan peningkatan kualitas perawatan (Mutisya, Karani, \& Kigondu, 2015). Perawat perlu memikirkan cara membuat intervensi keperawatan dengan biaya yang efektif (Mutisya, et al., 2015). Para pemimpin dan institusi perawatan kesehatan telah meningkatkan harapan untuk praktik berbasis bukti dalam upaya untuk meningkatkan hasil dan meningkatkan kualitas (Wilson, Sleutel, Newcomb, Behan, Walsh, Wells, \&
Baldwin, 2015) serta menurunkan biaya perawatan (Mutisya, et al., 2015; Wilson et al., 2015). Tujuan Institute of Medicine (IOM) adalah bahwa ditahun 2020, 90\% keputusan klinis harus berdasarkan bukti (IOM, 2011).

Budaya organisasi dan kesiapan untuk EBP di beberapa rumah sakit masih berada pada kategori sedang hingga rendah (Melnyk, GallagherFord, Thomas, Troseth, Wyngarden, \& Szalacha, 2016). Terhambatnya penerapan EBP dapat diakibatkan kurangnya kesiapan perawat untuk mengintegrasikan bukti ke dalam praktik, termasuk keyakinan perawat terhadap EBP dan kurangnya mentor EBP. Lebih dari separuh Chief Nursing Excecutives (CNE) dan Chief Nursing Officers (CNO) melaporkan bahwa mereka tidak mengakses basis data penting untuk panduan berbasis 
bukti atau tinjauan sistematis bukti (Melnyk et al., 2016). Perawat yang ada di pelayanan kesehatan banyak memiliki hambatan dalam penerapan praktik berbasis bukti diantaranya Kurangnya otoritas, kurangnya waktu dan hambatan bahasa (Wang, Jiang, Wang, Wang, \& Bai, 2013).

Penelitian yang dilakukan di Cina menunjukkan bahwa hal yang dapat memfasilitasi perawat dalam menerapkan EBP adalah dukungan manajerial $(36,9 \%)$, memajukan pendidikan untuk meningkatkan pengetahuan $(21,1 \%)$, meluangkan waktu untuk meninjau dan menerapkan EBP $(17,5 \%)$, serta meningkatkan dana dan kerjasama dengan pasien untuk pemanfaatan penelitian (Wang, et al., 2013).

Mengidentifikasi kemampuan perawat dalam menerapkan EBP merupakan langkah awal yang harus dilakukan para manajer keperawatan. Ada banyak jenis intrumen yang digunakan sebagai tools dalam mengukur pengetahuan dan keterampilan perawat terkait implementasi EBP. Oleh karena itu perlu indentifikasi instrumen yang tepat untuk mengukur pengetahuan dan keterampilan perawat dalam menerapkan EBP di rumah sakit.

\section{METODE}

Pencarian sumber dilakukan secara elektronik menggunakan database Pubmed (2014-2018) dan
Willey (2014-2018). Pencarian sekunder dilakukan dengan tidak membatasi tanggal publikasi. Strategi pencarian yang digunakan dalam bahasa inggris dengan menggunakan kata kunci "(()kill OR knowledge) AND (nurse OR nurse manager OR apn OR advanced practice nurse) AND (evidence-based nursing OR evidence-based nursing practice OR ebnp)))".

Pemilihan sumber referensi menggunakan kriteria yang telah ditentukan untuk memasukkan beberapa studi dalam kajian ini. Artikel yang di inklusi adalah artikel dengan dengan penerapan evidencebased practice, hasil data berbentuk kuantitatif dengan desain deskriptif analisis cross-sectional, tahun publikasi pada rentang tahun 20142018, dan publikasi full text (Tabel 1).

Critical Appraisal Skills Programme (CASP) Cross Sectional digunakan reviewer sebagai tools untuk mengekstraksi publikasi yang didapatkan. Secara independen, reviewer mengekstraksi data yang terkait latar belakang dan tujuan, metode, hasil, serta instrumen yang digunakan. Jika ada data yang tidak lengkap dari laporan publikasi maka secara otomatis publikasi tersebut akan dieksklusi, tidak ada upaya lain yang dilakukan reviewer untuk mendapatkan data yang dimaksud. Setiap kutipan kemudian dinilai terhadap kriteria inklusi/ eksklusi secara mandiri oleh dua reviewer (WH dan SS). 


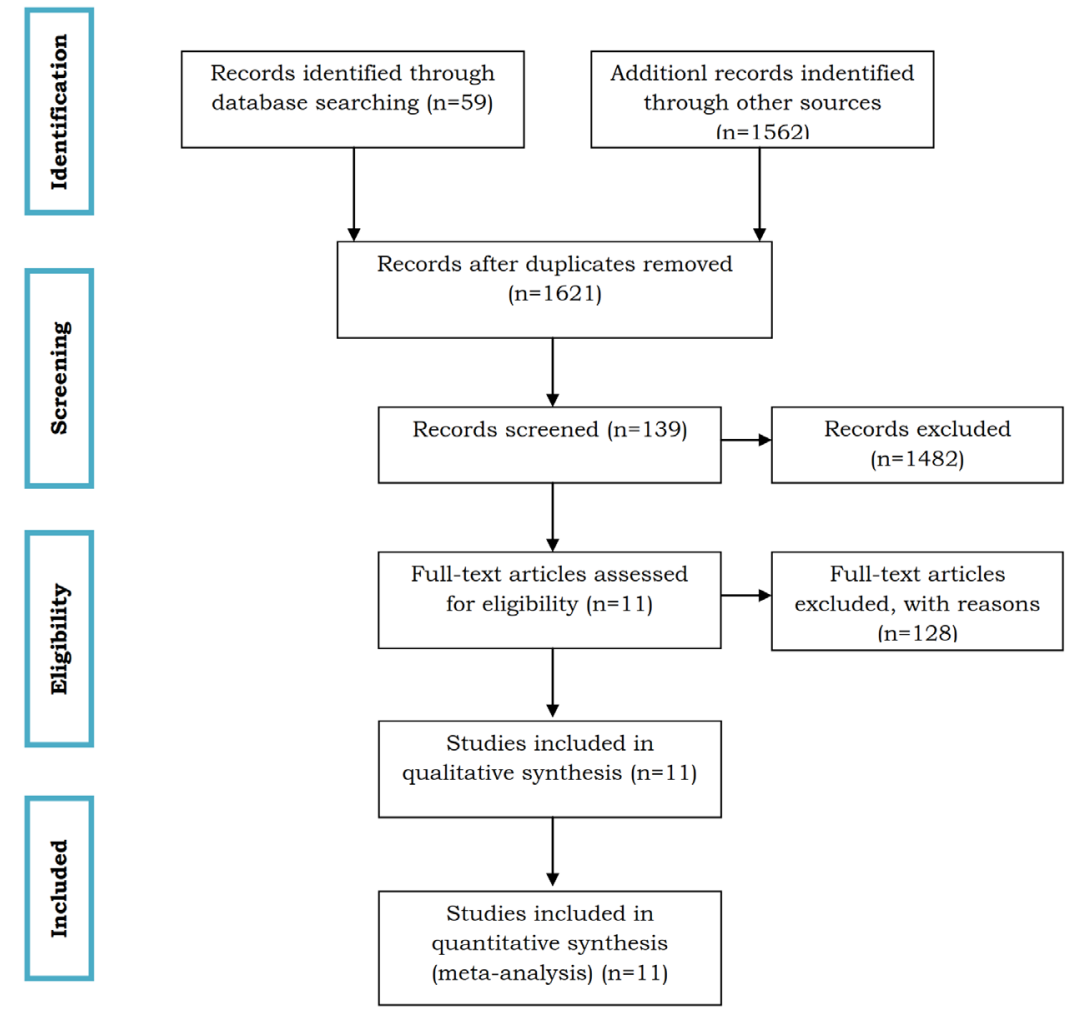

Gambar 1. Flow Chart Pencarian Artikel

\begin{tabular}{ll}
\hline Indikator & Kriteria Inklusi \\
\hline Sampel & Perawat \\
\hline Tipe penelitian & $\begin{array}{l}\text { Penelitian dengan desain analisis } \\
\text { cross-sectional }\end{array}$ \\
\hline Tahun publikasi & Penelitian publikasi 2014-2018 \\
\hline Hasil & Penerapan evidence-based practice \\
\hline Publikasi & Full text \\
\hline Bahasa & Artikel penelitian berbahasa inggris
\end{tabular}

Tabel 1. Karakteristik artikel yang diinklusi

\section{HASIL}

Profil pencarian literature disajikan dalam diagram alur (Gambar 1). Sebanyak 1621 publikasi diidentifikasi dari database. 1482 publikasi dikeluarkan karena bukan publikasi 5 tahun terakhir, bukan jurnal, dan tidak berbahasa inggris. Selanjutnya dari 139 publikasi yang ada, mengeluarkan 128 yang tidak sesuai variabel, bukan desain cross sectional dan tidak full text. Selanjutnya 11 penelitian ini dilakukan penilaian kelayakan untuk dijadikan referensi dengan menggunakan CASP crosssectional. Dengan demikian total 11 penelitian dimasukkan dalam analisis data secara deskriptif. Hasil sintesis Grid dari beberapa literature disajikan dalam Tabel 2 berikut. 


\begin{tabular}{|c|c|c|c|c|c|c|c|}
\hline $\begin{array}{c}\text { Penulis } \\
\text { Tahun }\end{array}$ & Negara & Judul & Tujuan & Metode & Sampel & Instrumen & Hasil Penelitian \\
\hline $\begin{array}{l}\text { Zhou et al., } \\
2016\end{array}$ & Cina & $\begin{array}{l}\text { A t t titude, } \\
\text { Knowledge, } \\
\text { and Practice on } \\
\text { Evidence-Based } \\
\text { Nursing } \\
a \quad m \text { m } n g \\
R \text { egistered } \\
\text { Nurses in } \\
\text { Traditional } \\
\text { C h i n e s e } \\
\text { Medicine } \\
\text { Hospitals: A } \\
\text { Multiple Center } \\
\text { Cross-Sectional } \\
\text { Survey in China }\end{array}$ & $\begin{array}{l}\text { 1. Untuk melihat } \\
\text { gambaran sikap, } \\
\text { pengetahuan dan } \\
\text { praktik perawat } \\
\text { dalam penerapan } \\
\text { EBP keperawatan } \\
\text { tradisional Cina. } \\
\text { 2. U } \mathrm{n} \mathrm{t} \quad \mathrm{k} \\
\text { memperkirakan } \\
\text { f a c t o r } \\
\text { sosiodemografi } \\
\text { dan professional } \\
\text { terkait }\end{array}$ & 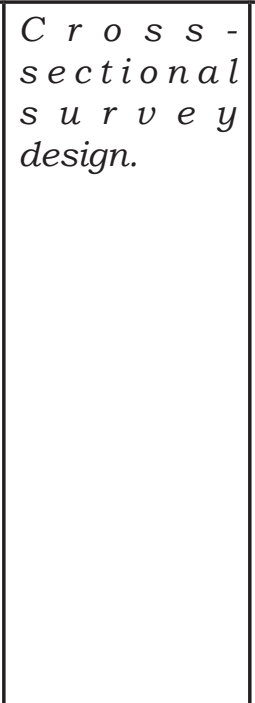 & \begin{tabular}{|l|} 
RN's y ang \\
berada diempat \\
rumah sakit \\
p e r a a t a n \\
tradiotional di \\
Beijing, Cina \\
berjumlah 648 \\
respomden
\end{tabular} & $\begin{array}{l}\text { E } B \text { P } \\
\text { Questionnaire } \\
\text { (EBPQ) dan } \\
\text { kuesioner yang } \\
\text { d i r a n c a n g } \\
\text { sendiri }\end{array}$ & $\begin{array}{l}\text { 1. Sikap perawat } \\
\text { cenderung lebih positif } \\
\text { jika dibandingkan } \\
\text { pengetahuan dan } \\
\text { praktik EBP. } \\
\text { 2. Pengalaman kerja, } \\
\text { posisi administrasi, } \\
\text { pengalaman penelitian, } \\
\text { beban kerja yang ringan } \\
\text { lebih lama pengalaman } \\
\text { kerja, memiliki posisi } \\
\text { administrasi, dan sikap } \\
\text { professional yang baik } \\
\text { mungkin memfasilitasi } \\
\text { EBP. }\end{array}$ \\
\hline $\begin{array}{l}\text { Camargo et } \\
\text { al., } 2016 .\end{array}$ & Brasil & $\begin{array}{l}\text { Assessment of } \\
\text { an intervention } \\
\text { for the diffusion } \\
\text { of evidence- } \\
\text { based nursing } \\
\text { in a teaching } \\
\text { hospital }\end{array}$ & $\begin{array}{l}\text { Untuk mengevaluasi } \\
\text { intervensi untuk } \\
\text { difusi praktik berbasis } \\
\text { bukti di antara para } \\
\text { pemimpin perawat dari } \\
\text { sebuah rumah sakit } \\
\text { pendidikan umum }\end{array}$ & $\begin{array}{l}\text { Quantitative } \\
\text { descriptive } \\
\text { study }\end{array}$ & 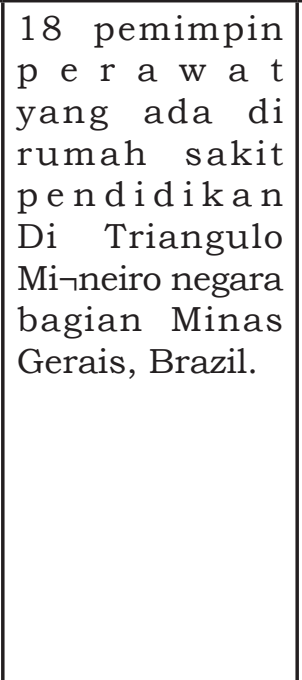 & $\begin{array}{l}\text { Ta hap 1, } \\
\text { menggunakan } \\
\text { E B P P } \\
\text { Questionnaire } \\
\text { (EBPQ) } \\
\text { Tahap II dan III, } \\
\text { menggunakan } \\
\text { the evaluation } \\
\text { of the actual } \\
\text { works ops: } \\
\text { Conceptual } \\
\text { Apprehension } \\
\text { of EBN, } \\
\text { Tahap IV, } \\
\text { hanya berupa } \\
\text { validasi data }\end{array}$ & $\begin{array}{l}\text { Para pemimpin perawat } \\
\text { memiliki sikap positif terhadap } \\
\text { penggabungan bukti penelitian } \\
\text { ke dalam praktik. Kesulitan } \\
\text { utama mereka adalah } \\
\text { kemampuan untuk memahami } \\
\text { penelitian Aspek motivasi } \\
\text { terkait dengan intervensi } \\
\text { memiliki indeks validitas isi } \\
\text { tertinggi }\end{array}$ \\
\hline
\end{tabular}




\begin{tabular}{|c|c|c|c|c|c|c|c|}
\hline $\begin{array}{l}\text { Penulis } \\
\text { Tahun }\end{array}$ & Negara & Judul & Tujuan & Metode & Sampel & Instrumen & Hasil Penelitian \\
\hline $\begin{array}{l}\text { Mutisya et } \\
\text { al.m, } 2015 \text {. }\end{array}$ & Kenya & $\begin{array}{l}\text { Res e a rch } \\
\text { Utilization } \\
\text { among Nurses } \\
\text { at a Teaching } \\
\text { Hospital in } \\
\text { Kenya }\end{array}$ & \begin{tabular}{|l} 
1. Untuk menilai \\
pemanfa ta n \\
penelitian oleh \\
perawat di rumah \\
sakit pendidikan \\
Kenyatta National \\
Hospital r \\
2. Faktor a pa \\
s a j a y a n g \\
mempengaruhi \\
peman fa a ta n \\
penelitian oleh \\
perawat di rumah \\
sakit pendidikan \\
Kenyatta National \\
Hospital
\end{tabular} & 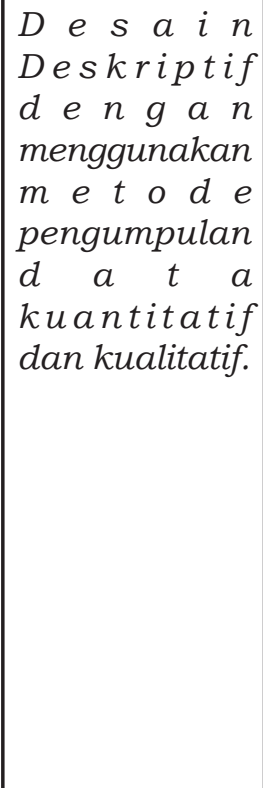 & $\begin{array}{l}\text { Perawat yang } \\
\text { berasal dari } \\
\text { unit perawatan } \\
\mathrm{k} \text { h u s u s } \\
\text { berjumlah } 183 \\
\text { orang. }\end{array}$ & $\begin{array}{l}\mathrm{D} \text { a } \quad \mathrm{t} \text { a } \\
\text { dikumpulkan } \\
\text { d e } \mathrm{n} \text { g a n } \\
\text { Kuesion er, } \\
\text { Focus Group } \\
\text { Discussion, } \\
\text { dan In-depth } \\
\text { Interview }\end{array}$ & $\begin{array}{l}\text { 1. } 2 / 3 \text { (70,5\%) dari } \\
\text { responden menerapkan } \\
\text { EBP berdasarkan } \\
\text { pengetahuan yang } \\
\text { mereka dapatkan } \\
\text { selama pendidikan } \\
\text { keperawatan. } \\
\text { 2. Tiga hambatan terbesar } \\
\text { untuk pemanfaatan } \\
\text { penelitian adalah bahwa } \\
\text { laporan penelitian } \\
\text { tidak tersedia }(68,7 \%), \\
\text { implikasi tidak jelas } \\
\text { untuk praktik }(66,5 \%) \\
\text { dan fasilitas yang } \\
\text { tidak memadai untuk } \\
\text { implementasi }(66,4 \%) .\end{array}$ \\
\hline $\begin{array}{l}\text { Shafiei et } \\
\text { al., } 2014 .\end{array}$ & Iran & 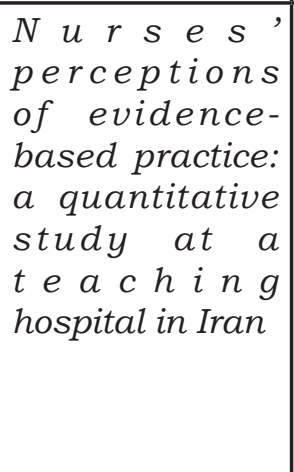 & $\begin{array}{l}\text { Untuk mengukur } \\
\text { praktik, sikap dan } \\
\text { p e n e t a h a d / } \\
\text { keterampilan praktik } \\
\text { berbasis bukti perawat } \\
\text { di Rumah Sakit } \\
\text { Pendidikan di Iran }\end{array}$ & 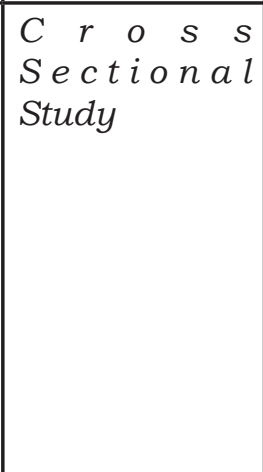 & $\begin{array}{l}195 \text { perawat } \\
\text { yang bekerja di } \\
\text { Rumah Sakit } \\
\text { Fatemeh Zahra } \\
\text { b e rafilias i } \\
\text { d e n g a n } \\
\text { B u s h e h r } \\
\text { University } \\
\text { of Medical } \\
\text { S c i e n c e s } \\
\text { (BPUMS). }\end{array}$ & $\begin{array}{l}\text { In s t r u m e n } \\
\text { survei adalah } \\
\text { k u e s i o n e r } \\
\text { berdas arkan } \\
\text { Upton \& Upton } \\
\text { Study (Upton \& } \\
\text { Upton, 2005). }\end{array}$ & $\begin{array}{l}\text { Tiga subskala praktek, } \\
\text { sikap dan pengetahuan } \\
\text { keterampilan dalam praktek } \\
\text { berbasis bukti, } 4,58 \pm 1,24, \\
4,57 \pm 1,35 \text { dan } 4,39 \pm 1,20, \\
\text { masing-masing. Ada hubungan } \\
\text { yang kuat antara pengetahuan } \\
\text { dan kinerja perawat }(r=0,73, \\
p<0,01) \text {. }\end{array}$ \\
\hline
\end{tabular}




\begin{tabular}{|c|c|c|c|c|c|c|c|}
\hline $\begin{array}{c}\text { Penulis } \\
\text { Tahun }\end{array}$ & Negara & Judul & Tujuan & Metode & Sampel & Instrumen & Hasil Penelitian \\
\hline $\begin{array}{l}\text { K 1 e i n - } \\
\text { Fedyshin, } \\
2016 .\end{array}$ & USA & $\begin{array}{l}\text { Translating } \\
\text { Evidence into } \\
\text { Practice at the } \\
\text { End-of-Life: } \\
\text { Information } \\
\text { needs, access } \\
\text { and usage by } \\
\text { hospice and } \\
\text { palliative nurses }\end{array}$ & 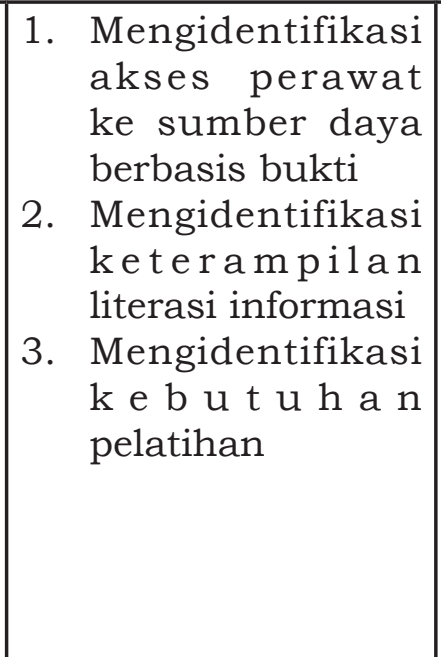 & \begin{tabular}{|l|} 
Descriptive \\
assessment \\
in online or \\
paper form
\end{tabular} & 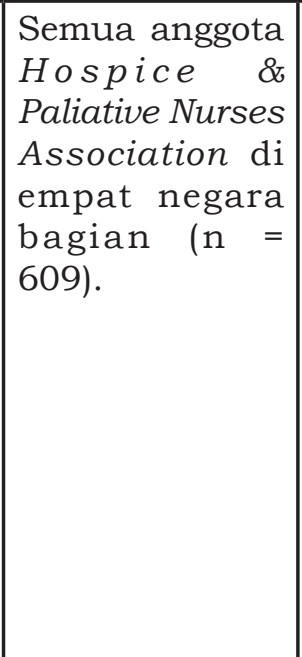 & \begin{tabular}{|l} 
Perceptions \\
of nurses of \\
evidence-based \\
practice (EBP) \\
questionnaire \\
oleh Majid, \\
2011 (Majid, \\
Luyt, Zhang, \\
Theng, \& \\
Mo k h t ar, \\
2011)
\end{tabular} & $\begin{array}{l}\text { 1. Sumber informasi yang } \\
\text { paling sering adalah } \\
\text { rekan kerja }(74 \%), \\
\text { diikuti oleh pencarian } \\
\text { Internet (70\%). } \\
\text { 2. Sekitar 43\% responden } \\
\text { m e r a a y a k i n } \\
\text { menggunakan strategi } \\
\text { literasi kesehatan. } \\
\text { 3. Kebutuhan pelatihan } \\
\text { terbes a a a la h } \\
\text { menemukan informasi } \\
\text { keperawatan berkualitas } \\
\text { (79\%). }\end{array}$ \\
\hline $\begin{array}{l}\text { Connor et } \\
\text { al., } 2017 \text {. }\end{array}$ & USA & $\begin{array}{l}\text { Me a s uring } \\
\text { Nurses'Value, } \\
\text { Implementation, } \\
\text { and Knowledge } \\
\text { of Evidence- } \\
\text { Based Practice: } \\
F \text { u } r \text { h } e r \\
\text { Psychometric } \\
\text { Testing of the } \\
\text { Quick-EBP-VIK } \\
\text { Survey }\end{array}$ & \begin{tabular}{|l} 
n t u k l e b i h \\
m e n g g a m b a r k a n \\
pengujian psikometrik \\
dari instrumen \\
Quick-EBrvei
\end{tabular} & $\begin{array}{l}\text { Descriptive } \\
\text { study } \\
\text { via a web- } \\
\text { based survey }\end{array}$ & \begin{tabular}{|l|} 
Semua perawat \\
yang memenuhi \\
syarat di rumah \\
sakit USA studi \\
m e n e r i m a \\
u n d a n g a n \\
e - m a i l \\
sebanyak 382 \\
responden
\end{tabular} & $\begin{array}{l}\text { The Quick-EBP- } \\
\text { VIK instrument } \\
\text { contains 25 } \\
\text { items measuring } \\
\text { three domains of } \\
\text { EBP-value (V), } \\
\text { implementation } \\
\text { (I), and } \\
\text { knowledge (K). }\end{array}$ & $\begin{array}{l}\text { Nilai-nilai Alpha Cronbach } \\
\text { untuk masing-masing dari } \\
\text { ketiga domain semuanya lebih } \\
\text { tinggi dari O,7 menunjukkan } \\
\text { bahwa item dari masing-masing } \\
\text { dimensi pengukuran konsisten } \\
\text { secara internal }\end{array}$ \\
\hline
\end{tabular}




\begin{tabular}{|c|c|c|c|c|c|c|c|}
\hline $\begin{array}{c}\text { Penulis } \\
\text { Tahun }\end{array}$ & Negara & Judul & Tujuan & Metode & Sampel & Instrumen & Hasil Penelitian \\
\hline $\begin{array}{l}\text { Melnyk et } \\
\text { al., } 2016 \text {. }\end{array}$ & USA & 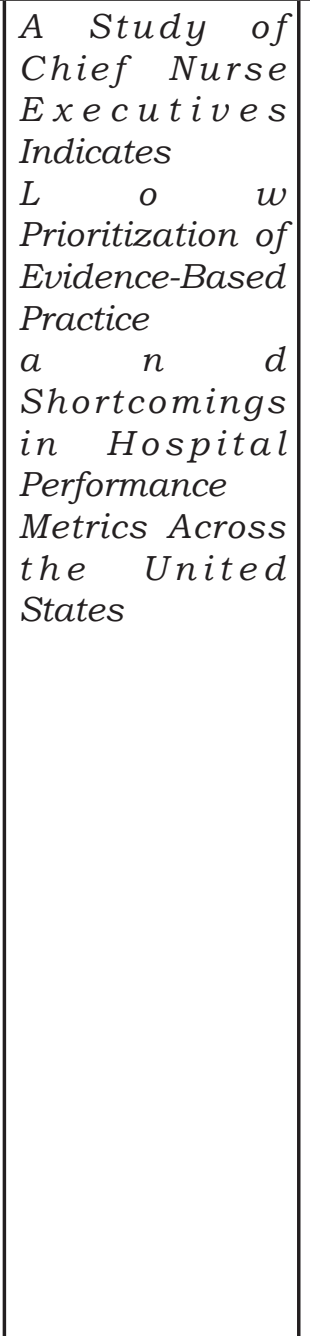 & 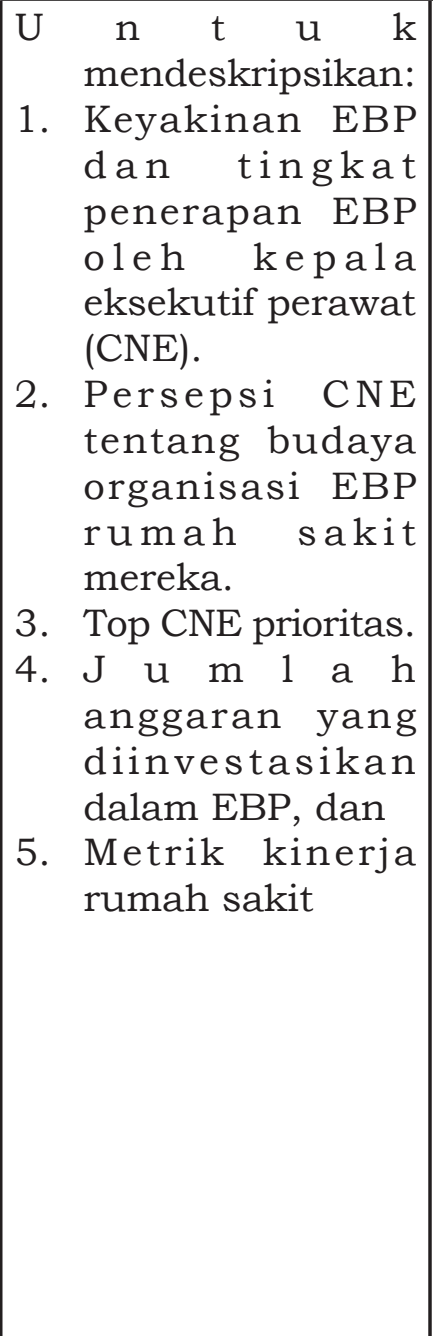 & 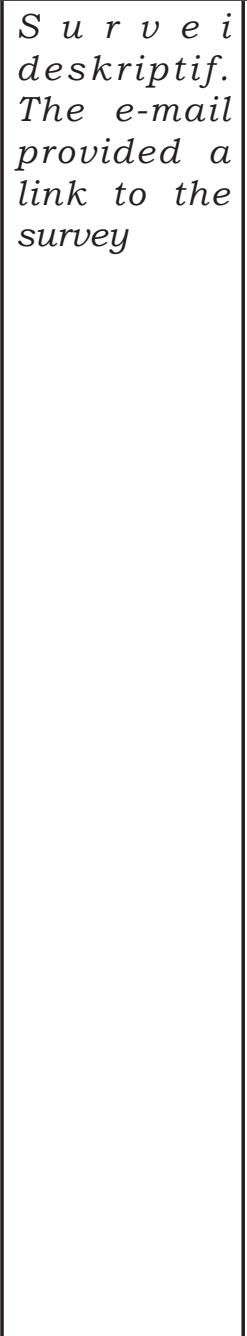 & $\begin{array}{|lll|}327 & \text { CNE } & \text { dan } \\
\text { CNO } & \text { di } & \text { yang } \\
\text { berasal dari } & 45 \\
\text { negara bagian } \\
\text { di } & \text { A merika } \\
\text { Serikat } & \text { dan } \\
\text { Kolumbia } & \end{array}$ & $\begin{array}{l}\text { The EBP Beliefs } \\
\text { scale; the EBP } \\
\text { Implementation } \\
\text { scale; the } \\
\text { Organizational } \\
\text { Culture and } \\
\text { Readiness scale } \\
\text { for EBP }\end{array}$ & $\begin{array}{l}\text { 1. Keyakinan CNO dan CNE } \\
\text { bahwa EBP dipraktekkan } \\
\text { di organisasinya dari "tidak } \\
\text { sama sekali" hingga "agak" } \\
\text { tinggi (60.17\%). } \\
\text { 2. Implementasi EBP oleh } \\
\text { CNE dan CNO sendiri } \\
\text { rendah sebesar } 27.8 \% \text {. } \\
\text { 3. Pri o r t a s u t a a a } \\
\text { sebagaimana dinyatakan } \\
\text { oleh perawat kepala adalah } \\
\text { kualitas dan keamanan, } \\
\text { namun E BP dikutip } \\
\text { sebagai prioritas utama } \\
\text { hanya 3\% dari kepala } \\
\text { perawat (Gambar } 3 \text { ). } \\
\text { 44\% dari CNO dan CNE } \\
\text { hanya menginvestasikan } \\
\text { 0\%-10\% dari anggaran } \\
\text { untuk membangun dan } \\
\text { mempertahankan EBP di } \\
\text { organisasi mereka. } \\
\text { Perawat kepala melaporkan } \\
\text { bahwa lebih dari 1/3 RS } \\
\text { mereka tidak memenuhi } \\
\text { tolak ukur NDNQI dan } \\
\text { hampir satu dari ketiga } \\
\text { rumah sakit berada di atas } \\
\text { tolak ukur nasional }\end{array}$ \\
\hline
\end{tabular}




\begin{tabular}{|c|c|c|c|c|c|c|c|}
\hline $\begin{array}{l}\text { Penulis } \\
\text { Tahun }\end{array}$ & Negara & Judul & Tujuan & Metode & Sampel & Instrumen & Hasil Penelitian \\
\hline $\begin{array}{l}\text { Saunders \& } \\
\text { Vehviläinen- } \\
\text { Julkunen, } \\
2017\end{array}$ & Finlandia & $\begin{array}{l}N u r \text { s e s } \\
\text { Evidence-Based } \\
\text { Practice Beliefs } \\
\text { and the Role of } \\
\text { Evidence-Based } \\
\text { Practice } \\
\text { Mentors at } \\
\text { University } \\
\text { Hospitals in } \\
\text { Finland }\end{array}$ & $\begin{array}{l}\text { Untuk menentukan } \\
\text { keyakinan } \\
\text { dan peran } \text { EBP } \\
\text { EBP di rumah } \\
\text { sakit universitas } \\
\text { Finlandia dan untuk } \\
\text { mengeks plorasi } \\
\text { hubungan antara } \\
\text { keyakinan EBP } \\
\text { RN dan faktor } \\
\text { sosiodemografi }\end{array}$ & $\begin{array}{l}\text { A cross- } \\
\text { sectional } \\
\text { descriptive } \\
\text { survey }\end{array}$ & $\begin{array}{l}\text { RN yang bekerja } \\
\text { di Rumah Sakit } \\
\text { Un i ve r s it a s } \\
\text { F i n } 1 \text { a n d i a } \\
\text { berjumlah } 943 \\
\text { sampel. }\end{array}$ & 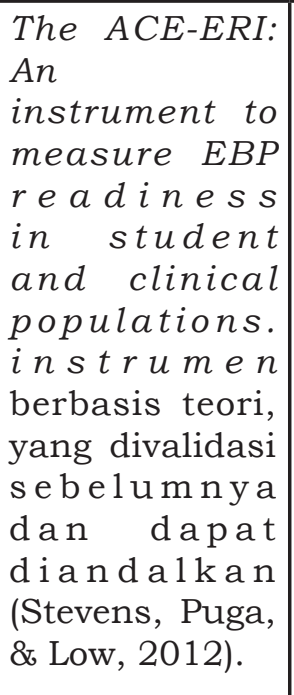 & $\begin{array}{l}\text { RN melaporkan tingkat } \\
\text { rendah keyakinan EBP } \\
\text { dalam tingkat di mana } \\
\text { mereka percaya bahwa } \\
\text { praktik keperawatan } \\
\text { klinis dan praktik mereka } \\
\text { sendiri didasarkan pada } \\
\text { bukti. Mentor EBP } \\
\text { bekerja di banyak peran } \\
\text { keperawatan profesional. } \\
\text { Beberapa perbedaan } \\
\text { signifikan ditemukan } \\
\text { antara keyakinan } \\
\text { EBP RN dan variabel } \\
\text { sosiodemograf. }\end{array}$ \\
\hline $\begin{array}{l}\text { Verloo et al., } \\
2016 .\end{array}$ & Swiss & $\begin{array}{l}\text { Beliefs and } \\
\text { implementation } \\
\text { of evidence- } \\
\text { based practice } \\
\text { among } \\
\text { nurses and } \\
\text { allied healthcare } \\
\text { providers in the } \\
\text { Valais hospital, } \\
\text { Switzerland }\end{array}$ & $\begin{array}{l}\text { Untuk menyelidiki } \\
\text { keyakinan tentang } \\
\text { dan implementasi } \\
\text { EBP di antara perawat } \\
\text { dan aliansi penyedia } \\
\text { layanan kesehatan } \\
\text { (Allied Healthcare } \\
\text { Providers) }\end{array}$ & $\begin{array}{l}\text { A cross } \\
\text { sectional } \\
\text { descriptive } \\
\text { survey }\end{array}$ & $\begin{array}{l}2025 \text { sampel } \\
\text { yang terdiri dari } \\
1899 \text { perawat } \\
\text { dan } 126 \text { AHP } \\
\text { yang berasal } \\
\text { dari } 9 \text { rumah } \\
\text { sakit perawatan } \\
\text { akut di kanton } \\
\text { Valais, Swiss }\end{array}$ & $\begin{array}{l}\text { EBP Beliefs } \\
(E B P B) \text { and } E B P \\
\text { Implementation } \\
(E B P I) \text { scales }\end{array}$ & $\begin{array}{l}\text { Secara keseluruhan, peserta } \\
\text { memiliki sikap positif } \\
\text { terhadap EBP dan bersedia } \\
\text { meningkatkan pengetahuan } \\
\text { mereka untuk memandu } \\
\text { praktek. Namun, mereka } \\
\text { mengakui implementasi } \\
\text { EBP yang buruk dalam } \\
\text { praktek sehari-hari. Tingkat } \\
\text { implementasi EBP yang } \\
\text { lebih tinggi dinyatakan } \\
\text { oleh mereka yang dilatih } \\
\text { secara formal di dalamnya } \\
\text { dan oleh mereka yang } \\
\text { menduduki lebih banyak } \\
\text { fungsi profesional senior. }\end{array}$ \\
\hline
\end{tabular}




\begin{tabular}{|c|c|c|c|c|c|c|c|}
\hline $\begin{array}{c}\text { Penulis } \\
\text { Tahun }\end{array}$ & Negara & Judul & Tujuan & Metode & Sampel & Instrumen & Hasil Penelitian \\
\hline $\begin{array}{l}\text { Weng et al., } \\
2015 .\end{array}$ & \begin{tabular}{|l|} 
Taiwan, \\
Republik \\
Tiongkok
\end{tabular} & \begin{tabular}{|l|} 
Implementation \\
of Evidence- \\
Based Practice \\
in Relation to a \\
Clinical Nursing \\
Ladder \\
Syste m: A \\
National Survey \\
in Taiwan
\end{tabular} & \begin{tabular}{|lr} 
Untuk mengevaluasi \\
apakah & penerapan \\
E B P & t e 1 a h \\
dimasukkan ke \\
Clinical & Ladder \\
System &
\end{tabular} & $\begin{array}{l}\text { A cross- } \\
\text { sectional } \\
\text { questionnaire } \\
\text { survey }\end{array}$ & $\begin{array}{l}4026 \text { perawat } \\
\text { yang berasal } \\
\text { dari } 11 \text { rumah } \\
\text { sakit regional } \\
\text { Taiwan }\end{array}$ & $\begin{array}{l}\text { Questionnaire } \\
\text { The survey } \\
\text { included items } \\
\text { for measuring } \\
\text { the profile of } \\
\text { EBP- } \\
\text { including the } \\
\text { a w a r e e s } \\
\text { of beliefs } \\
\text { in, attitudes } \\
\text { t o w a r d , } \\
\text { knowledge } \\
\text { of, skills in, and } \\
\text { behaviors of } \\
\text { EBP. }\end{array}$ & $\begin{array}{l}\text { Perawat tingkat lanjut } \\
\text { lebih sadar akan EBP } \\
\text { dibandingkan perawat } \\
\text { awal. Selain itu, perawat } \\
\text { tingkat lanjut lebih } \\
\text { cenderung memiliki } \\
\text { keyakinan positif dan } \\
\text { sikap terhadap EBP dan } \\
\text { memiliki pengetahuan dan } \\
\text { keterampilan yang lebih } \\
\text { memadai dalam EBP. }\end{array}$ \\
\hline \begin{tabular}{|l|} 
Wilson et al., \\
2015.
\end{tabular} & USA & \begin{tabular}{|l|} 
Empowering \\
Nurses With \\
Evidence-Based \\
$P$ a c t i c e \\
Environments: \\
Surve y ing \\
Magnet R_, \\
Pathway to \\
Excellence R_, \\
and Non-Magnet \\
Facilities in \\
One Healthcare \\
System
\end{tabular} & $\begin{array}{l}\text { Untuk menentukan } \\
\text { a paka h kualita s } \\
\text { individu atau organisasi } \\
\text { dapat diidentifikasi yang } \\
\text { terkait dengan kesiapan } \\
\text { perawat terdaftar (RNs) } \\
\text { untuk EBP yang diukur } \\
\text { dengan hambatan EBP, } \\
\text { kemampuan, keinginan, } \\
\text { dan frekuensi perilaku } \\
\text { yang dilaporkan }\end{array}$ & $\begin{array}{l}\text { A } \begin{array}{l}\text { descriptive } \\
c \\
\text { s r o o s s s }\end{array} \\
\text { survey }\end{array}$ & $\begin{array}{l}\text { 2.441 perawat } \\
\text { dalam satu } \\
\text { s i s t e m } \\
\text { k e s e h a t a n } \\
\text { Amerika Serikat }\end{array}$ & $\begin{array}{l}\text { Questionnaire } \\
\text { The survey } \\
\text { included items } \\
\text { for measuring } \\
\text { the profile of } \\
\text { EBP- } \\
\text { including the } \\
\text { a w a r e e s } \\
\text { of beliefs } \\
\text { in, attitudes } \\
\text { t o w a r d , } \\
\text { knowledge } \\
\text { of, skills in, and } \\
\text { behaviors of } \\
\text { EBP. }\end{array}$ & $\begin{array}{l}\text { RN dididik pada tingkat } \\
\text { sarjana muda atau lebih tinggi } \\
\text { melaporkan hambatan lebih } \\
\text { sedikit untuk EBP daripada } \\
\text { perawat dengan pendidikan } \\
\text { yang lebih sedikit; mereka } \\
\text { juga memiliki kemampuan } \\
\text { EBP, keinginan, dan frekuensi } \\
\text { perilaku yang lebih tinggi. } \\
\text { Model prediktif menemukan } \\
\text { skor kesiapan EBP yang } \\
\text { lebih tinggi di antara RN } \\
\text { yang berpartisipasi dalam } \\
\text { penelitian, memiliki keahlian } \\
\text { khusus } \\
\text { sertifikasi, dan terlibat dalam } \\
\text { program pengembangan karir } \\
\text { klinis. }\end{array}$ \\
\hline
\end{tabular}




\section{PEMBAHASAN}

Semua penelitian menggunakan desain peneletian cross-sectional dengan sampel perawat yang bekerja di rumah sakit. Kebanyakan penelitian tidak hanya mengukur pengetahuan dan keterampilan perawat penerapan EBP tetapi juga keyakinan perawat (Saunders \& Vehviläinen-Julkunen, 2017; Weng et al., 2015), sikap perawat (Zhou, Hao, Gou, \& Liu, 2016; Camargo, Iwamoto, Monteiro, Lorena, \& Pereira, 2016; Mutisya et al., 2015; Shafiei, Baratimamani, Goharinezhad, Kalhor, \& Azmal, 2014; Verloo, Demestd, \& Morin, 2016), dan hambatan penerapan EBP (Camargo et al., 2016; Mutisya et al., 2015). Bahkan dalam penelitian Melnyk (2016) lebih jauh dijelaskan mengenai peran para manajer perawat dalam pengimplementasian EBP dan anggaran yang disediakan rumah sakit terkait praktik berbasis bukti.

Beberapa penelitian diantaranya menggunakan instrumen berbasis online (Connor, Paul, McCabe, \& Zinil, 2016; Melnyk et al., 2016), dan selebihnya menggunakan lembar instrumen. Pengumpulan data tidak hanya menggunakan instrumen untuk mengukur pengetahuan dan keterampilan perawat dalam penerapan EBP tetapi juga beberapa penelitian menggabungkan dengan teknik pengumpulan data yang lain seperti focus group discussion dan Indepth interview (Mustisya et al., 2015). Terdapat beberapa jenis intrumen untuk mengukur pengetahuan dan keterampilan perawat dalam penerapan EBP (Tabel 2). Sebagian besar Instrumen yang digunakan adalah jenis instrumen yang telah ditetapkan (Camargo et al., 2016; Melnyk et al., 2016; Verloo et al., 2016; Weng, Chen, Kou, Yang, Chen, \& Chiu, 2015; \& Wilson et al., 2015). Namun beberapa penelitian menunjukkan instumen yang digunakan adalah instrumen yang dikembangkan oleh peneliti lain (Safhiei et al., 2014; Saunders \& Vehviläinen-Julkunen, 2017; KleinFedsyhin, 2016). Bahkan peneliti dapat membuat dan mengembangkan sendiri instrumen yang dianggap sesuai untuk mengukur pengetahuan dan keterampilan perawat terkait EBP (Zhou, 2016).

Bukti awal menunjukkan bahwa instumen $E B P$ Belief (EBPB) and $E B P$ Implementation (EBPI) Scale lebih sering digunakan dalam mengukur keyakinan dan keterampilan perawat dalam penerapan EBP (Melnyk et al., 2016 $\&$ Verloo et al., 2016). Namun ulasan penelitian yang lain menunjukkan bahwa banyak instrumen yang dapat digunakan untuk menilai pengetahuan dan keterampilan perawat terkait EBP. Shafie et al (2014) menggunakan instrumen dari Upton \& Upton Study untuk mengukur praktik, sikap dan pengetahuan/ keterampilan perawat dalam praktik berbasis bukti di rumah sakit. Perceptions of nurses of evidencebased practice (EBP) questionnaire merupakan instrumen yang dikembangkan oleh Majid pada tahun 2011, dan digunakan untuk mengukur kemampuan dan keterampilan perawat dalam menerapkan EBP (Klein-Fedsyin, 2016).

Dari 11 publikasi yang dianalisis, hanya ada 2 publikasi yang menggunakan instrumen yang sama. Namun bukan berarti instrumen digunakan peneliti lain tidak valid. Hal ini menunjukkan bahwa tersedianya berbagai jenis instrumen yang digunakan dalam mengukur pengetahuan dan keterampilan perawat memberikan peluang untuk memilih jenis instrumen yang sesuai. Meskipun belum dapat dipastikan jenis instrumen mana yang lebih baik, tetapi $E B P$ Questionnaire (EBPQ) dapat dijadikan pilihan karena pertanyaan dalam instrumen tersebut lebih fokus ke pengetahuan dan keterampilan perawat dalam menerapkan EBP.

Kekuatan tinjauan ini terletak pada pendekatan sistematis untuk mencari, menyaring, dan meninjau studi serta mengolah hasil publikasi dengan standar yang ada. Desain penelitian yang digunakan hanya 
menggunakan satu desian saja sehingga data yang ditampilkan dapat diseragamkan.

Review ini memiliki beberapa keterbatasan dimana penilaian penelitian hanya melibatkan dua orang saja (WH dan SS) sehingga resiko bias masih dapat terjadi. Jenis penelitian yang dimasukkan hanya penelitian dengan cross-sectional design sehingga sampel dalam peneltitian ini masih kecil. Selain itu, penelitian dengan menggunakan satu metode saja dapat memberikan hasil yang berbeda jika memasukkan semua desain penelitian yang ada.

\section{SIMPULAN}

Hasil literature review ini belum dapat menjelaskan instrumen mana yang lebih baik untuk digunakan dalam mengukur pengetahuan dan keterampilan perawat. Meskipun demikian, secara umum hasil ulasan ini memberikan informasi terkait pilihan instrumen yang dapat digunakan dipelayanan kesehatan seperti rumah sakit.

\section{DAFTAR PUSTAKA}

Camargo, F. C., Iwamoto, H. H., Monteiro, D. A. T., Lorena, L. T., \& Pereira, G. D. (2016). Assessment of an intervention for the diffusion of evidence-based nursing in a teaching hospital. Revista Gaucha de Enfermagem. Retrieved from http:// dx.doi.org/10.1590/1983- 1447.2016. esp. 68962

Connor, L., Paul, F., McCabe, M., \& Ziniel, S. (2017). Measuring Nurses' Value, Implementation, and Knowledge of Evidence-Based Practice: Further Psychometric Testing of the Quick-EBP-VIK Survey. Worldviews on Evidence-Based Nursing. 14 (1), 10-21. Retrieved from doi:10.1111/wvn. 12190

Institute of Medicine. (2011). The Future of Nursing: Leading Change, Advancing Health. Washington (DC): National Academies Press

KARS. (2017). Standar Nasional Akreditas Rumah Sakit (SNARS) (1st ed.). Jakarta: Komisi Akreditasi Rumah Sakit. https:// doi.org/10.1080/02713683.2017.1402 486

Klein-Fedyshin, M. (2016). Translating Evidence into Practice at the End-of-Life: Information needs, access and usage by hospice and palliative nurses. $J$ Hosp Palliat Nurs. 17 (1), 24-30. Retrieved from doi:10.1097/ NJH.0000000000000117

Majid, S., Foo, S., Luyt, B., Zhang, X., Theng, Y., \& Mokhtar, I. A. (2011). Adopting evidence-based practice in clinical decision making: nurses' perceptions, knowledge, and barriers. Journal of the Medical Library Association. 99 (3), 229236. Retrieved from doi:10.3163/15365050.99.3.010

Melnyk, B. M., Gallagher-Ford, L., Thomas, B. K., Troseth, M., Wyngarden, K., \& Szalacha, L. (2016). A Study of Chief Nurse Executives Indicates Low Prioritization of Evidence-Based Practice and Shortcomings in Hospital Performance Metrics Across the United States. Worldviews on EvidenceBased Nursing.13 (1), 6-14. Retrieved from doi:10.1111/wvn.12133

Mutisya, A. K., Karani, A. K., \& Kigondu, C. (2015). Research Utilization among Nurses at a Teaching Hospital in Kenya. Journal of Caring Sciences. 4 (2), 95-104. Retrieved from doi:10.15171/jcs.2015.010

Saunders, H., \& Vehviläinen-Julkunen, K. (2017). Nurses' Evidence-Based Practice Beliefs and the Role of Evidence-Based Practice Mentors at University Hospitals in Finland. Worldviews on Evidence-Based Nursing. 14 (1), 35-45. Retrieved froim doi:10.1111/wvn.12189

Shafiei, E., Baratimarnani, A., Goharinezhad, S., Kalhor, R., \& Azmal, M. (2014). Nurses' perceptions of evidence-based practice: a quantitative study at a teaching hospital in Iran. Medical Journal of the Islami8c Republic of Iran (MJIRI). 28 (135), 1-7. Retrieved from https://www.ncbi.nlm. nih.gov/pubmed/?term=Nurses $\% \mathrm{E} 2 \% 80$ $\% 99+$ perceptions + of +evidence-based + pr actice $\% 3 \mathrm{~A}+\mathrm{a}+$ quantitative + study $+\mathrm{at}+\mathrm{a}+\mathrm{t}$ eaching+hospital+in+Iran

Stevens, K. R., Puga, F., \& Low, V. (2012). The ACE-ERI: An instrument to measure $E B P$ readiness in student and clinical populations. Retrieved from https://isrn. net/sites/isrn/files/documents/ACEERI.pdf

Upton, D., \& Upton, P. (2005). Nusres' attitudes to evidence based practice: impact of a national policy. British Journal of Nursing. 14 (5). Retrieved from https:// doi.org/10.12968/bjon.2005.14.5.17666

Verloo, H., Desmedt, M., \& Morin, D. (2016). Beliefs and implementation of evidencebased practice among nurses and allied healthcare providers in the Valais hospital, Switzerland. Journal of Evaluation in Clinical Practice. 139-148. Retrieved from https://doi.org/10.1111/ jep. 12653

Wang, L., Jiang, X., Wang, L., Wang, G., \& Bai, Y. (2013). Barriers to and Facilitators of Research Utilization: A Survey of 
Registered Nurses in China. Plos One. 8 (11). Retrieved from doi: 10.1371/journal. pone.0081908

Weng, Y., Chen, C., Kou, K. N., Yang, C., Lo, H., Chen, K., \& Chiu, Y. (2015). Implementation of Evidence-Based Practice in Relation to a Clinical Nursing Ladder System: A National Survey in Taiwan. Worldviews on Evidence-Based Nursing. 12 (1), 22-30. Retrieved from doi:10.1111/ wvn. 12076

Wilson, M., Sleutel. M., Newcomb, P., Behan, D., Walsh, J., Wells, J. N., \& Baldwin, K. M. (2015). Empowering Nurses With EvidenceBased Practice Environments: Surveying
Magnet, Pathway to Excellence, and Non-Magnet Facilities in One Healthcare System. Worldviews on Evidence-Based Nursing. 12 (1), 12-21. Retrieved from doi:10.1111/wvn. 12077

Zhou, F., Hao, Y., Gou, H., \& Liu, H. (2016). Attitude, Knowledge, and Practice on Evidence-Based Nursing among Registered Nurses in Traditional Chinese Medicine Hospitals: A Multiple Center CrossSectional Survey in China. EvidenceBased Complementary and Alternative Medicine. Retrieved from http://dx.doi. org/10.1155/2016/5478086 